THURSDAY, FEBRUARY $\mathbf{1 4}, 1878$

\section{MR. STANLEY}

$S^{\operatorname{IR}}$ R SAMUEL BAKER spoke the truth on Thursday night last in St. James's Hall when he told Mr. Stanley that the Prince of Wales might be regarded as the spokesman of the nation when he addressed the great explorer in warm words of welcome and admiration. Not for many years has there been so much excitement in London as there was on Thursday in connection with the wild rumours on the state of affairs in the East; it seemed as if people could not possibly have a shred of attention to bestow on any other matter, but nearly two hours before the time at which the meeting of the Geographical Society was to commence the doors of St. James's Hall were besieged by an eager crowd ; and many hundreds, if not thousands, had to be left out in the distribution of tickets. The welcome which Mr. Stanley received could not possibly have been more enthusiastic. In view of the many hard words that have been spoken of Mr. Stanley's conduct under certain trying circumstances, the sight on the platform of the stately figure and genial face of the venerable missionary and explorer, Dr. Moffat, father-in-law of Livingstone, was exceedingly gratifying, showing, as we think it did, that so humane and experienced an "African" as he does not consider that Mr. Stanley has greatly sinned.

That Mr. Stanley should be received with all the enthusiasm of hero-worship by the civilised world is just what might have been expected. It is seldom, however, that a hero receives the glory due to his heroism so promptly as Mr. Stanley has done, especially when that glory has been earned in the field of exploration. Hitherto it has only been through the tardy medium of a book that the public at home have learned of an explorer's work; but in Mr. Stanley's case we have been able to watch his progress step by step by means of the eagerly-looked-for letters he sent home from the heart of Africa, like spectators watching the progress of an assault against a hitherto impregnable stronghold. Thus when Stanley emerged once more into "the light of common day" the very first white man at Emboma into whose hands that memorable appeal for help came knew at once that one of the greatest deeds of all time had been accomplished.

The exact grade to be allotted to Mr. Stanley among the dii majores of explorers must be left to a future generation, but this we may be sure of that when the man and his work shall stand clearly out against the "azure of the past," when all the accidental circumstances that accompanied the ever-memorable journey shall have been forgotten, Mr. Stanley will take his place among the foremost of pioneer explorers, as one of the greatest benefactors to humanity and science. $\mathrm{He}$, indeed, has shown that there is work in the world for many generations of men of science, and it will be long after the region has been opened up to commerce ere science will have obtained an adequate knowledge of its treasures.

Mr. Stanley has been termed "the Bismarck of African exploration;" as Bismarck has united into one great empire the fragmentary states of Germany, so has Stanley by the work he has accomplished united into one great whole the disjecta membra of African exploration. But the likeness between the two men extends further than this; in the one case as in the other there has been a well-defined purpose carried out by means of a clear and cool head, firm nerve, unflinching will, and (perhaps more important than all) an iron constitution.

What then has Mr. Stanley done to justify the enthusiasm with which he has been universally received by high and low, by learned and unlearned ?

One of the most remarkable characteristics of his work is the unprecedented rapidity with which it was accomplished, considering the rich harvest of results. As he told his followers at Zanzibar he meant to do, he shot across the continent like an arrow. In two years and a haif, with many zigzags and subsidiary explorations, Africa was crossed from Bagamoyo to the mouth of the Congo. The great work of the expedition, the exploration of the Lualaba from Nyangwe to the sea occupied only five months; looking at it in all its aspects, no explorer ever did so great a work in anything like the time.

For thousands of years has the Nile been a mystery which civilised humanity has never ceased to seek to penetrate; no other geographical problem, not even the pole itself, has had such a fascination for Europe. Many and many a life has been sacrificed in the attempt to find the source of the sacred stream, and it was in seeking this goal that Livingstone wandered away south to find "the fountains of Herodotus," only to find a grave on the marshy shore of Lake Bangweolo. The glory of virtually settling the problem has remained to Livingstone's discoverer and pupil, Stanley. In his march northwards from Ugogo to Lake Victoria Nyanza, the explorer came upon a river which flows into the south of that lake, the river Shimeeyu, about 350 miles long, which may be regarded as one of the most remote, if not the most remote, of the sources of the old Nile. Further, into the west side of the lake flows Speke's Kitangule river, which Mr. Stanley has re-baptised the Alexandra Nile; this river the latter explored with much thoroughness while staying at the court of the gentle Rumanika. He found it to be a broad lake-river, giving off many lagoons, one of them Speke's Lake Windermere, and having its source in Speke's Lake Akanyaru (now the Alexandra Nyanza) which again has, Mr. Stanley believes, a river of considerable length flowing into its west side, and another coming from the south, having its origin on the east of Lake Tanganyika. Here then, no doubt, we have the ultimate sources of the Nile, which have been sought for since history began. Mr. Stanley, we believe, has virtually set the question at rest, though we are sure he will willingly share the credit of the discovery with Speke, whose geographical instinct was astonishing, and the essential accuracy of whose discoveries have been throughout confirmed by his successor.

For the first time we have, through Mr. Stanley's exploration, an approximately accurate idea of the outline and extent of Lake Victoria Nyanza. Any map of Africa published two years ago shows this lake in a triangular shape, with an offshoot in its north-east corner. Mr. Stanley has broadened it out into an irregular square, with a coast-line of about 1,000 miles in length, studded with islands, many of them inhabited, and its shores peopled by many different tribes.

The geography of the region between Victoria Nyanza and Albert Nyanza may now be plotted with considerable 
fulness aiter the work of Mr. Stanley, who, however, was unable to carry out the plan of doing for the Albert what he did for the Victoria. Through one of the valleys which run north and south between the mountains of this region flows another tributary of the Alexandra Nyanza, and on Mount Gambaragara dwell those mysterious fair-skinned people that Speke heard of, but specimens of whom Mr. Stanley actually saw. About the time of Mr. Stanley's visit, we may remind the reader, Signor Gessi explored the Albert Lake, and we believe, to judge from his narrative, was unwittingly driven to its southern shore, about $\mathrm{x}^{\circ} \mathrm{S}$. lat. Quite recently, as we recorded at the time, Col. Mason has sailed round the lake, and reports it to be comparatively small and land-locked, with no important affluent other than the Victoria Nile.

On Lake Tanganyika Mr. Stanley completed the work of his predecessors. He circumnavigated the lake, and for the first time accurately plotted the outline of its southern part, adding considerably to our knowledge of the people and products of its shores. We have already spoken at some length of his examination of the Lukuga, which Cameron set down on the middle of the western shore as the long-sought-for outlet of the lake. Stanley examined the Lukuga with great care, and concludes that at present it is only a creek, but that as the waters of the lake are encroaching on the shore, either by the rise of the former or subsidence of the latter, the Lukuga will, in a very short time, actually become an outlet. What $\mathrm{Mr}$. Stanley has told us of the lake and the surrounding region is well calculated to whet the curiosity of the geologist and physical geographer. We have already alluded to Mr. Stanley's theory of the past physical history of the region; but even if his knowledge of geology were adequate to the formation of an acceptable theory, he had scarcely time enough to collect the necessary data. Here, at any rate, is a splendid field for the seologists of the future.

Had Mr. Stanley returned home after his exploration of Tanganyika, or had the toss between himself and poor Pocock been "tails to go south" and leave the problem of the Lualaba unsolved, no one would have blamed him, and his work in the Nyanza region would have added very considerably to his previous reputation as an explorer. But his daring dash down the Lualaba is a coup that has immortalised him; it has done for him what the publication of "Pickwick" did for Dickens, it has compelled the world to admit that in his own line he is a genius of the first rank. Indeed we cannot but regard the spirit which animated Stanley at this crisis of his journey in Africa as a really heroic one. He himself happily and aptly expressed it in his address at St. James's Hall by quoting the words which Tennyson puts into the mouth of Ulysses, and which he applied to the position of himself and his followers when they were left by their Arab escort on the broad bosom of the Lualaba, at the very gate of the unknown region :-

\footnotetext{
"My mariners,

Souls that have toil'd, and wrought, and thought with me, -

'Tis not too late to seek a newer world. Come, my friends,

Push off, and sitting well in order smite

The sounding furrows; for my purpose holds

To sail beyond the sunset, and the baths

Or ail the western stars, until I die.
}

It may be that the gulfs will wash us down :

It may be we shall touch the Happy Isles

And see the great Achilles whom we knew.

Though much is taken, much abides; and tho'

We are not now that strength which in old days

Moved earth and heaveu; that which we are, we are;

One equal temper of heroic hearts,

Made weak by time and fate, but strong in will

To strive, to seek, to find, and not to yield."

The mouth of the Congo has been known since the Portuguese, in the fifteenth century, began to creep down the African coast, and Tuckey, in the beginning of the present century, traced it about 150 miles to the lower cataracts. Its origin and course was one of the few, probably the greatest of remaining, mysteries in geography. Long ago the Pombeiros and other travellers came across streams inland from the Portuguese possessions in south-west Africa, which run northwards, and latterly Livingstone made known the great river Lualaba, which, however, against all evidence, he believed to be connected with the Nile. One of the principal streams known, at least since the time of the Pombeiros, is the Casai, a considerable river running northwards, and which some geographers maintained must be the upper course of the Congo. Others again maintained, and the reports of the natives seemed to confirm it, that in the region between Nyangwe on the Lualaba and the sea, was a great lake into which that and other rivers flowed, while some seemed to think that the Lualaba ran southwards, and probably ultimately flowed into Lake Chad. Livingstone, as we have said, thought the Lualaba belonged to the Nile, while Cameron was convinced it was the Upper Congo, but that it flowed almost straight westwards. The solution of the problem was a task well calculated to fascinate a man like Stanley, a task in which all his rare qualities as an explorer would be developed to the utmost, but a task for which he has proved himself easily equal. It is difficult, indeed, to see how the work could have been accomplished for generations except by a man of Stanley's character, and by the method adopted by him. In whatever light we regard this part of his recent work in Africa-whether as a mere exploit, or as a vast addition to geographical knowledge, or in the light of the great results that are likely to follow to civilisation, commerce, and science-it has scarcely, if ever, been surpassed in the history of geographical exploration. We have in previous numbers shown the magnitude and importance of this discovery. In the course of a few months, by the daring genius of one man, there has been thrown open to our knowledge a river of the first rank, watering a region of apparently exhaustless resources both for the man of science and the trader. It is about 3,oco miles long, has many large tributaries, themselves affording many hundred miles of navigable water; waters a basin of nearly a million square miles, and pours into the sea a volume estimated at $1,800,000$ cubic feet per second. Such a piece of work is surely enough to immortalise a man.

Such, briefly, is the work accomplished in so short a space by the Commissioner of the Telegraph and the Horald, a work which he set about as a mere piece of business in connection with his calling of special correspondent, but for which Mr. Bennett had the insight to see he was unusually well adapted. A private business enterprise has thus accomplished what the much-instructed and 
elaborately-equipped expeditions of learned societies have failed to do. It would be a pity were Mr. Stanley's exceptional aptitude for the work of exploration allowed to lie fallow. Even in the basin of the Congo much remains to be done, and we doubt if any great results will follow the Portuguese expedition which Mr. Stanley met at Loanda. There is also South America, the centre of which is now more unknown than Central Africa, and which awaits a pioneer like Stanley to show the way to the minute explorer and surveyor. It is stated that $\mathrm{Mr}$ Gordon Bennett contemplates equipping a polar expedition, so that we fear he thinks he has done enough for Africa. But whether or not Mr. Stanley again enters the field as an explorer, he has written his name in indelible letters alongside that of Livingstone, on the heart of Africa.

\section{WAS GALILEO TORTURED?}

Ist Galilei gefoltert worden? Eine kritische Studie. Von Emil Wohlwill. (Leipzig: Duncker and Humblot, 1877.)

THIS work treats with exhaustive thoroughness a question first raised about a century ago, as early, in fact, as advancing political liberty rendered its public discussion consistent with personal safety, and which has occupied scientific biographers pretty continuously since that time. The author's main object in reopening an issue, which the majority of recent authorities consider as settled in the negative, is to bring into due prominence the bearing on it of fresh evidence rendered accessible only within the last ten years. $U_{p}$ to 1867 , though it was known that a cletailed official record of Cralileo's trial was preserved in the archives of the Inquisition, only a few isolated and questionable extracts from it had been made public. In that year, however, M. Henri de L'Epinois, by permission of the Papal authorities, published in antenso the most important of the documents contained in the trial-record. These, supplemented by still more recent corrections and additions, which it is unnecessary to particularise here, supplied a body of new evidence bearing more or less directly on the issue whether the Roman Inquisition, in its treatment of the great astronomer, had recourse in any degree to that test of physical endurance which formed a recognised part of its procedure as of that of contemporary secular courts in cases like his.

It was of course to be expected that in documents drawn up exclusively for the use of the Inquisition itself there would occur a number of technical expressions the exact meaning of which would be far from obvious to a reader unacquainted with the details of procedure in the holy office. This accordingly turns out to be the fact, and interposes no slight obstacle to the interpretation of the fresh evidence thus presented. Wohlwill, in order to overcome it, has put himself through an elaborate course of Inquisitional literature, studying minutely the fixed technical forms for conducting suits in the holy office laid down in manuals and instructions published for the guidance of its own officials. It is obvious how firm is the foundation thus to be secured in comparison with the precarious guessing which would otherwise be inevitable. The tasks both of preliminary inquiry and of subsequent application, have been performed with the utmost diligence, accuracy, ancl sagacity.
It would be impossible, within the limits of this notice, to enter upon the detailed arguments by which Wohlwill supports his views. All that can here be done is to state the chief results at which he arrives, together, where feasible, with some indication of the line by which he has travelled.

The final sentence delivexed by the Inquisition in Galileo's case contains a statement that the court had judged it necessary to proceed against him to "the rigorous examination." 1 Libri had, as early as I84I, asserted, on the authority of various inquisitional manuals, and in particular of one entitled "Sacro Arsenale della S. Inquisizione," that "esame rigoroso" ${ }^{2}$ was exactly equivalent to "torture," and that this passage of the sentence was absolutely decisive of the whole question. Wohlwill shows, by a complete scrutiny of the "Sacro Arsenale," that a "rigorous" examination in most cases meant one conducted under torture, but that this expression sometimes denoted a less severe procedure. It appears that where the course of the preliminary investigation led the judges. to suspect that the accused had not stated the entire truth, three distinct and increasingly intense trials of fortitude and endurance were prescribed for successive adoption. First the prisoner was brought into the ordinary hall of audience and told briefly and sternly that unless he could make up his mind to confess the truth, recourse would be had to the torture. If this produced no result, he was next carried into the torturechamber, where the use of the various instruments was explained to him, or he was even seized by the attendants, stripped of his clothes, and bound upon the rack, so that nothing remained but to set its machinery in action. In this situation he was again invited to save himself by confession. If he still remained firm, the infliction of the torture at once ensued. The two preliminary appeals to terror were described as the "verbal scaring" (tcrritio achalis), and the "real scaring" (icritic realis), while the words "rigorous examination" were reserved, strictly speaking, for the final scene of actual agony. It is clear, however, from passages of the "Sacro Mrsenale," that in certain cases confessions elicited by the second method of proceeding were described as made under the rigorous examination, though this laxity of expression is explicitly stated not to extend to the first. The text of the sentence against Galileo therefore implies, at the least, that he was carried into the torture-chamber and submitted to some form of the territio realis.

The same authoritative document informs us what was the general character of his replies under this ordeal. He answered "in a catholic manner," i.c., denied that he held the reputedly heretical doctrines attributed to him. While stating this fact the Court were careful to insert a saving clause that the answers so given were not to prejudice other points admitted by or proved against the accused. The significance of this clause, which preceding writers appear to have passed unnoticed, is, according to Wohlwill, as follows :- So great was the regard professed by the Inquisition for assertions steadfastly adhered to under the torture, that in regard to whatever formed the actual subject-matter of a rigorous examination, the answers of the accused, if he thus stood by them, had to be

r "Gindicassimts csser necessario venir contro di te al rigoroso esane."

Wohwill has shown that !ralian, aud not, as has litherto been assuned, tatin, wats the language in which the sentence was promulgated. 